\title{
USULAN PERBAIKAN KUALITAS PROSES PRODUKSI WAFER ABON DENGAN METODE SIX SIGMA
}

\author{
Riyan $^{1}$, Heksa Bekti Ariyono ${ }^{2}$ \\ ${ }_{1,2}$ Program Studi Teknik Industri, Universitas Bunda Mulia, Jakarta \\ e-mail: oyan.kurniawan@gmail.com ${ }^{1}$
}

Received: November 11, 2016; Accepted: January 26, 2017

\begin{abstract}
ABSTRAK
Paper ini membahas penelitian yang dilakukan pada industri makanan dengan berbagai produk makanan ringan seperti roti, wafer cream, cookies, wafer stick, chocolate, dan dry cake. Perusahaan harus selalu meningkatkan kualitas proses dan produk sesuai dengan tuntutan konsumen. Metode Six Sigma diharapkan dapat membantu mengatasi meningkatkan kualitas proses dan produk yang terjadi dalam perusahaan. Six sigma adalah suatu pendekatan quality system model terkini yang dapat dimanfaatkan didalam fungsi industrialisasi yang bergerak dalam sektor manufaktur maupun sektor-sektor jasa pelayanan. Secara umum strategi six sigma lebih mengutamakan kepada pendekatan DMAIC (Define-Measure-AnalyzeImprove-Control). Batasan penanganan masalah adalah difokuskan pada produk wafer abon, karena dinilai oleh perusahaan memberi kontribusi jumlah cacat yang besar. Prioritas penanganan masalah juga dibatasi pada kedua proses utama dalam produksi, proses oven and cooling sheet dan proses creaming and pressing. Dimana proses creaming and pressing yang difokuskan untuk perbaikan, hal ini dikarenakan persentase defect yang disumbangkan proses ini cukup besar, yaitu sebesar 65\%. Berdasarkan pengolahan data didapat bahwa COPQ selama 1 bulan sebesar Rp. Rp. 65,473,200, - dan terdapat 3 CTQ yang menjadi prioritas dalam penyelesaian masalah yaitu untuk kategori cacat Pasta Tidak Rata (53.68\%), Hancur Pinggir (16.29\%), dan Retak (16.12\%). Hasil kapabilitas proses sebesar $91.51 \%$ dan level sigma yang dicapai dari produk wafer abon sebesar 3.647628 sigma. Analisis dilakukan dengan brainstorming untuk mengetahui penyebab defect yang kemudian disusun dalam fishbone diagram dan five why diagram. Usulan perbaikan yang diberikan antara lain membuat spesifikasi standar yang jelas mengenai setelan mesin oven dan creaming.
\end{abstract}

Kata Kunci: Quality Control, Six Sigma, DMAIC

\begin{abstract}
This paper discusses a conducted research in the food industry with a variety of snack products such as bread, cream wafers, cookies, wafer sticks, chocolate, and dry cake. The company should always improve the quality of processes and products according to customer demands. Six Sigma method is expected to improve the quality of process and product in the company. Six Sigma is a quality system approach to be used in the industrialization function engaged in the manufacturing and services sectors. Generally, six sigma strategy utilizes DMAIC approach (Define-Measure-Analyze-Improve-Control). This research focused on product wafers abon, because it contributed a large number of defects. Moreover, this paper discusses two main processes:1. oven and cooling sheet process, 2. creaming and pressing process. The improvement is focused in the creaming and pressing process, because it presents $65 \%$ of defects. Based on the obtained data processing, COPQ for 1 month is Rp. 65,473,200, - and there are 3 priority CTQ's in the issues, Pasta Tidak Rata (53.68\%), Crashed Edge (16.29\%), and Crack (16.12\%). Results of capability process are $91.51 \%$ and sigma level of wafer abon product is 3.647628 sigma. An analysis has been done by brainstorming to find the cause of the defect and then arranged in a fishbone diagram and five why's diagram. Proposed improvements including to create specification given standards for setup oven and creaming machine.
\end{abstract}

Keyword: Quality Control, Six Sigma, DMAIC 


\section{PENDAhuluaN}

\subsection{Latar Belakang}

Kualitas menjadi sangat penting dalam memilih produk di samping faktor harga yang bersaing. Perbaikan dan peningkatan kualitas produk dengan harapan tercapainya tingkat cacat produk mendekati zero defect membutuhkan biaya yang tidak sedikit. Suatu perusahaan dikatakan berkualitas bila perusahaan tersebut mempunyai sistem produksi yang baik dengan proses terkendali. Hal ini berhubungan dengan proses produksi dan kualitas produk yang dihasilkan.

Meminimumkan cacat adalah usaha yang harus dilakukan secara berkesinambungan, salah satunya dengan menerapkan metode Six Sigma (Gaspersz, 2002). Melalui penekanan pada kemampuan proses (process capability), perusahaan dapat mengharapkan 3,4 kegagalan persejuta (DPM). Hal yang harus dilakukan adalah menentukan karakteristik kualitas yang diinginkan pelanggan (CTQ) dan melihat sejauh mana produk yang dibuat tidak memenuhi apa yang diinginkan oleh konsumen, (Gaspersz, 2002). Six sigma merupakan suatu metode untuk strategi pengembangan bisnis guna mendapatkan dan mengurangi cacat dari suatu perusahaan. Metode six sigma sangat kuat dalam mengurangi cost, meningkatkan keuntungan dan pendapatan dari perusahaan tersebut (Mikel dan Schroeder, 2006).

Objek penelitian merupakan perusahaan yang bergerak pada industri makanan dengan berbagai produk makanan ringan seperti roti, wafer cream, cookies, wafer stick, chocolate, dan dry cake. Metode Six Sigma dapat membantu mengatasi meningkatkan kualitas proses dan produk yang terjadi dalam perusahaan. Secara umum strategi six sigma lebih mengutamakan kepada pendekatan DMAIC (Define - Measure - Analyze - Improve Control). Metode Six Sigma mengarahkan kepada persentase cacat yang sangat kecil atau dengan kata lain berusaha untuk mencapai tujuan zero defect dalam produk dengan cara mengukur, menganalisis, memperbaiki dan mengendalikan proses untuk menghilangkan cacat yang menyebabkan pemborosan biaya bagi perusahaan serta berusaha menghasilkan variasi kecacatan yang kecil. Sehingga perusahaan dapat memberikan kepuasan bagi setiap konsumennya dengan memenuhi kebutuhan konsumennya dengan produk yang berkualitas pada waktu yang tepat serta dapat memberikan harga yang kompetitif bagi konsumennya. Penelitian ini bertujuan untuk mendapatkan suatu solusi yang tepat untuk mengurangi tingkat cacat. Dengan tingkat cacat yang rendah, pemenuhan kebutuhan pelanggan akan menjadi lebih cepat dan baik.

\subsection{Perumusan Masalah}

Hal yang perlu diperhatikan dalam penelitian ini adalah mengurangi produk cacat dan meningkatkan kualitas produk yang dihasilkan, yang selama ini menjadi permasalahan yang sedang dihadapi perusahaan. Dengan adanya produk cacat yang ditemukan dalam proses produksi maupun produk jadi maka akan menyebabkan tingginya biaya produksi yang harus dikeluarkan perusahaan dan pelanggan akan merasa tidak puas dengan produk yang dihasilkan serta beralih pada produk pesaing yang lebih bagus kualitasnya. Tujuan dari penelitian ini adalah untuk mengetahui bagaimana penerapan proses produksi yang dilaksanakan oleh perusahaan untuk menjaga kualitas dari output yang dihasilkan dan kaitannya dalam menemukan faktorfaktor yang harus diperbaiki untuk meningkatkan performa dari perusahaan.

Dari jenis-jenis produk makanan perusahaan ini akan dipilih satu produk yaitu produk wafer abon yang mempunyai tingkat cacat cukup tinggi. Pada produk ini akan dilakukan penelitian lebih lanjut mengenai pengendalian kualitas dan pengendalian proses produksinya. Selain itu penelitian ini tidak mencakup kepada keseluruhan proses produksi wafer abon, namun dibatasi pada dua proses produksi yaitu proses oven and cooling sheet, dan proses creaming and pressing. 
Data yang digunakan adalah data jumlah produksi wafer abon beserta dengan persentase cacat-nya masing-masing. Data tersebut berada pada Maret 2013 dengan jenis-jenis cacat yang terjadi beserta persentase masing-masing. Penelitian hanya mencakup pemberian saran pada perbaikan proses produksi untuk peningkatan dan pengendalian kualitas pada hasil produksi produk wafer abon dengan metode DMAIC (Six Sigma).

\section{TINJAUAN PUSTAKA}

\subsection{Strategi Penerapan Six Sigma}

Dalam penerapan six sigma, terdapat 8 (delapan) tahap dasar, yaitu identifikasi (identify), definisi (define), pengukuran (measure), analisis (analyze), perbaikan (improve), kontrol (control), standar (standardize) dan integrasi (integrate). Inti dari strategi ini adalah tahap MeasureAnalyze-Improve-Control. Namun, tahap definisi sering dimasukkan ke dalam inti strategi six sigma, sehingga tahapannya menjadi Define-Measure-Analyze-ImproveControl.

Fase-fase DMAIC:

1. Define: mengklarifikasi masalah, tujuan dan proses. Membuat pernyataan masalah sedapat mungkin spesifik dan berdasarkan fakta, fokuskan kepada apa yang dapat diamati dan disusun, bukan pada perkiraan atau asumsi-asumsi.

2. Measure: mendasarkan dan menyaring masalah. Melakukan validasi atau menyaring masalah dan memulai meneliti akar masalah, memperhatikan output yang dihasilkan dan melihat pengaruhnya terhadap pengguna sistem, serta menemukan komponen yang paling signifikan pada masalah, sehingga analisis dan solusi akan ditargetkan dengan baik.

3. Analyze: analisis akar masalah. Melihat pada proses dan data untuk mengidentifikasi penyebab-penyebab yang mungkin, menemukan penyebab yang diperkirakan dan berusaha melakukan validasi melalui analisis.

4. Improve: menghasilkan, memilih dan mengimplementasikan solusi-solusi.
Menemukan ide-ide yang mungkin akan membantu kita mengatasi akar masalah dan mencapai tujuan, menentukan ide mana yang menjadi solusi-solusi potensial, memilih solusi yang paling tepat dengan biaya dan gangguan yang paling sedikit.

5. Control: memperbaiki kesalahankesalahan yang muncul setelah pengimplementasian dan menetapkan standar untuk menjaga efektivitas kinerja serta melakukan review.

\subsection{Critical to Quality (CTQ)}

Output dari sebuah proses dapat berupa produk maupun jasa. Variabel output dapat berupa waktu delivery atau dimensi dari produk itu sendiri. Kunci penting dari output biasanya dikategorikan berdasarkan pengaruhnya (area of impact), yaitu critical to quality, critical to cost, critical to delivery dan critical to process (Breyfogle, 1999). Critical to Quality (CTQ) adalah berbagai persyaratan yang dikehendaki oleh pelanggan terhadap suatu produk atau jasa. Gaspersz (2002) menjelaskan bahwa CTQ merupakan karakteristik kualitas yang ditetapkan seyogyanya berhubungan langsung dengan kebutuhan spesifik pelanggan, yang diturunkan secara langsung dari persyaratan-persyaratan output dan pelayanan. Kebutuhan spesifik pelanggan harus dapat diterjemahkan secara tepat ke dalam karakteristik kualitas yang ditetapkan oleh manajemen organisasi.

\subsection{Biaya Akibat Kualitas yang Buruk (Cost of Poor Quality)}

Kualitas produk yang buruk akan mengakibatkan kerugian dalam suatu nilai tertentu baik bagi produsen maupun konsumen. Perusahaan yang memiliki proses pada tingkat 3 sigma akan kehilangan 25-40\% dari total penjualan sebagai biaya kualitas (cost of quality) mereka. Sedangkan untuk perusahaan dengan tingkat sigma mencapai 6 sigma hanya akan kehilangan 5\% dari total penjualan mereka sebagai biaya kualitas. Keterkaitan antara tingkat sigma, DPMO serta COPQ dapat dilihat pada Tabel 1. 
Tabel 1. Hubungan Tingkat Sigma, DPMO serta COPQ

\begin{tabular}{|l|l|l|}
\hline $\begin{array}{c}\text { Tingkat } \\
\text { Pencapaian } \\
\text { Sigma }\end{array}$ & \multicolumn{1}{|c|}{ DPMO } & \multicolumn{1}{c|}{ COPQ } \\
\hline 1-sigma & $\begin{array}{l}\text { 691.462 (sangat } \\
\text { tidak kompetitif) }\end{array}$ & $\begin{array}{l}\text { Tidak dapat } \\
\text { dihitung }\end{array}$ \\
\hline 2-sigma & $\begin{array}{l}\text { 308.538 (rata-rata } \\
\text { industri } \\
\text { Indonesia) }\end{array}$ & $\begin{array}{l}\text { Tidak dapat } \\
\text { dihitung }\end{array}$ \\
\hline 3-sigma & 66.807 & $\begin{array}{l}\text { 25-40\% dari } \\
\text { penjualan }\end{array}$ \\
\hline 4-sigma & $\begin{array}{l}\text { 6.210 (rata-rata } \\
\text { industri USA) }\end{array}$ & $\begin{array}{l}\text { 15-25\% dari } \\
\text { penjualan }\end{array}$ \\
\hline 5-sigma & $\begin{array}{l}\text { 233 } \\
\text { 5-15\% dari } \\
\text { penjualan }\end{array}$ \\
\hline 6-sigma & $\begin{array}{l}\text { 3,4 (industri kelas } \\
\text { dunia) }\end{array}$ & $\begin{array}{l}\text { 1\% dari } \\
\text { penjualan }\end{array}$ \\
\hline $\begin{array}{l}\text { Setiap peningkatan atau pergeseran 1-sigma } \\
\text { akan memberikan peningkatan keuntungan } \\
\text { sekitar 10\% dari penjualan }\end{array}$ & \\
\hline
\end{tabular}

Sumber: Gasperz (2002)

\subsection{Pengukuran Kinerja Baseline}

Six sigma adalah metode yang bertujuan untuk meningkatkan kualitas. Parameter yang dapat dijadikan dasar dalam pengukuran tingkat kinerja (Baseline kinerja) adalah DPMO dan/atau tingkat kapabilitas proses. Dengan demikian, peningkatan kualitas akan dapat terukur melalui perbandingan nilai-nilai tersebut.

Defects Per Million Opportunities merupakan peluang terjadinya cacat untuk satu karakteristik yang penting bagi kualitas pada satu produk di dalam satu juta kemungkinan. Perhitungan DPMO dan Tingkat Sigma untuk data atribut dapat dilakukan sesuai langkah-langkah perhitungan berikut ini (Pande, 2007):

1. Defect Per Unit (DPU). Ukuran ini merefleksikan jumlah rata-rata dari cacat, semua jenis, terhadap jumlah total unit dari unit yang dijadikan sampel. Perhitungan DPU tercantum dalam persamaan (1)

$$
D P U=\frac{D}{U}
$$

dimana:

$\mathrm{D}=$ jumlah defective atau jumlah kecacatan yang terjadi dalam proses produksi
$\mathrm{U}=$ jumlah unit yang diperiksa

2. Defect Per Opportunity (DPO). Persamaan (2) menunjukkan proporsi cacat atas jumlah total peluang dalam sebuah kelompok.

$$
D P O=\frac{D}{(U)(O P)}
$$

dimana:

OP $($ Opportunity $)=$ karakteristik yang berpotensi untuk menjadi cacat.

3. Defect Per Million Opportunities (DPMO). DPMO mengindikasikan berapa banyak cacat akan muncul jika ada satu juta peluang.

$\mathrm{DPMO}=(\mathrm{DPO})(1.000 .000)$

4. Mengkonversikan nilai DPMO menggunakan tabel konversi untuk mengetahui tingkat sigma pada proses.

5. Perhitungan tingkat sigma dapat dengan mudah dihitung dengan menggunakan Microsoft Excel yaitu dengan menggunakan formula (3) (Evan dan Lindsay, 2007):

Level Sigma $=$

normsinv $\left(\frac{1000000-D P M O}{1000000}\right)+1.5$

\section{METODOLOGI PENELITIAN}

Dalam menjawab permasalahan yang ada pada penelitian ini, digunakan metode DMAIC. Tahapan pengolahan data terangkum pada Gambar 1.

Berdasarkan data yang didapat pada tahap pengumpulan data, selanjutnya dilakukan beberapa tahap pengolahan data dan analisis dengan metode DMAIC yang terdiri dari 5 tahap sebagai berikut:

1. Tahap Define

a. Pembuatan diagram alir proses

Pada tahap ini dibuat diagram alir proses yang berguna untuk melihat aktivitas proses produksi.

b. Pemilihan Proses

Untuk menghasilkan produk wafer abon melewati berbagai proses yang meliputi proses mixing receipt, oven, creaming, cutting, packaging, packing hingga warehousing. 


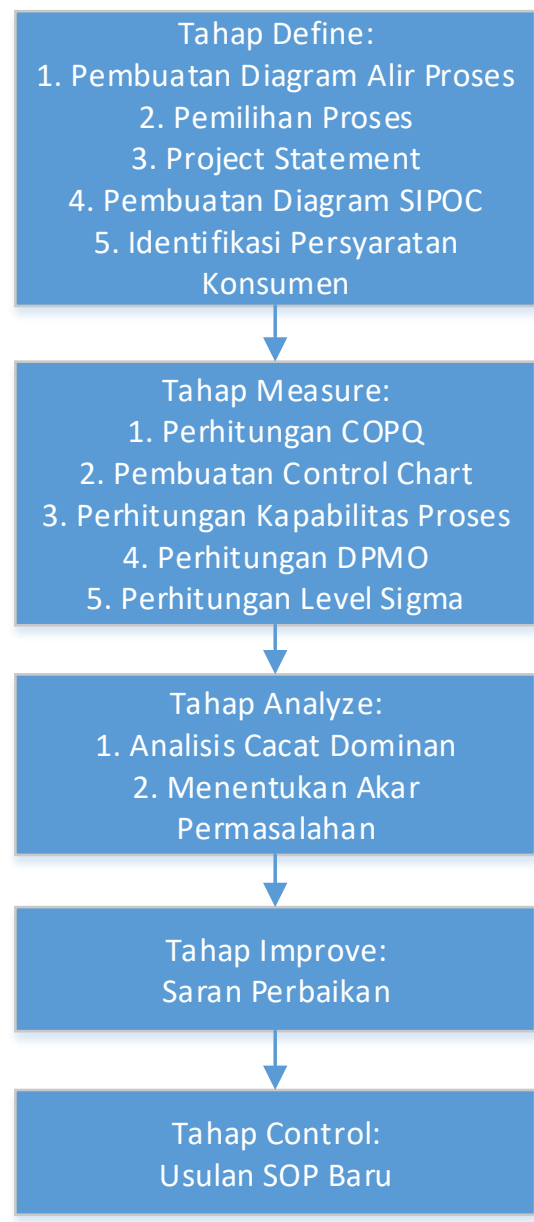

Gambar 1. Tahapan Pengolahan Data

c. Project Statement

Dalam tahap ini dijelaskan secara garis besar proyek yang akan diteliti, berupa latar belakang dipilihnya proyek tersebut dan, permasalahan apa saja yang terjadi. Selain itu juga dijelaskan sejauh mana lingkup proyek, tujuan yang ingin dicapai dari dilakukan proyek, dan batas waktu pelaksanaan proyek tersebut.

d. Diagram SIPOC (Supliers, Input, Processes, Outputs, Customers)

Diagram SIPOC digunakan untuk menggambarkan interaksi dari berbagai pihak yang terkait dalam proses penyediaan bahan baku, produksi hingga pengemasan produk jadi. Diagram SIPOC menjelaskan alur perpindahan bahan baku hingga menjadi produk jadi dengan komponen Supliers, Input, Processes,
Outputs, dan Customers pada masingmasing proses yang terjadi.

e. Identifikasi Persyaratan Konsumen dan Menetapkan CTQ (Critical to Quality)

Pada bagian ini dilakukan kegiatan identifikasi kebutuhan pelanggan terhadap produk. Kebutuhan pelanggan inilah yang akan menjadi dasar penentuan CTQ yaitu karakteristik kualitas terhadap produk.

2. Tahap Measure

a. Perhitungan COPQ, untuk menghitung biaya yang dikeluarkan oleh perusahaan karena adanya produk cacat.

b. Pembuatan Control chart, untuk melihat apakah proses masih dalam batas kendali atau tidak.

c. Perhitungan Kapabilitas Proses, untuk melihat kemampuan proses dalam menghasilkan produk yang sesuai dengan ekspektasi pelanggan.

d. Perhitungan DPMO dan level sigma. Tahap ini dilakukan dengan menghitung nilai DPMO jenis produk yang dipilih dan dikonversikan menjadi level sigma untuk mengetahui pada level manakah kualitas produk berada.

3. Tahap Analyze

a. Anaslisa cacat dominan dengan Diagram Pareto.

Pembuatan diagram pareto ditujukan untuk melihat jenis defect yang dominan terjadi pada jenis produk yang dipilih.

b. Menentukan akar pemasalahan dengan diagram fishbone.

Pembuatan diagram fishbone ditujukan untuk mengidentifikasi faktor-faktor penyebab kecacatan melalui 5 faktor yaitu man, method, machine, material, dan environtment untuk setiap jenis defect yang terjadi.

4. Tahap Improve

Saran Perbaikan. Pada tahap ini akan dilakukan rencana tindakan perbaikan untuk menggambarkan solusi-solusi yang diberikan. 
5. Tahap Control

a. Membuat suatu SOP (Standard Operational Procedure) yang baru dengan perbaikan-perbaikan seperti yang telah disarankan.

\section{HASIL DAN PEMBAHASAN}

\subsection{Tahap Define}

1. Pembuatan Diagram Alir Proses.

Alur proses produksi dari pembuatan wafer abon dijelaskan pada Gambar 2 . Uraian mengenai urutan alur proses produksi wafer abon adalah sebagai berikut:

a. Mixing receipt: merupakan proses penimbangan dan pencampuran bahan-bahan baku pembentuk yang digunakan untuk menghasilkan wafer abon.

b. Oven and cooling sheet: merupakan proses pemasakan dari bahan-bahan atau resep yang sudah dicampur sebelumnya.

c. Creaming and pressing: setelah melewati proses pendinginan, sheetsheet wafer menuju proses creaming, yaitu proses pemberian cream rasa abon sapi.

d. Inspection: tahap pengecekan. Pada tahap ini operator memeriksa kondisi dari wafer abon secara keseluruhan lalu menimbang berat dari wafer abon.

e. Cutting: tahap pemotongan. Wafer abon yang ukuran besar yang telah lolos dari inspeksi, dipotong dalam ukuran kecil sesuai dengan spesifikasi sesuai dengan ukuran kemasan satuan yang akan dijual di pasar.

f. Packaging and packing: tahap pengemasan dan pengepakan.

g. Warehousing: pada tahap ini, wafer yang sudah dikemas dan dikepak didalam dus, menuju gudang untuk disimpan dan siap untuk dipasarkan.

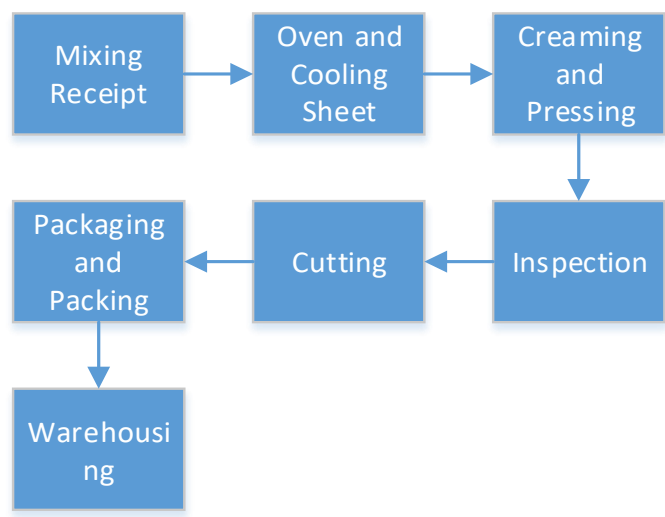

Gambar 2. Alur Proses Produksi Wafer Abon

2. Pemilihan Proses

Gambar 3 menampilkan diagram batang perbandingan jumlah rata-rata persentase cacat produk yang disebabkan oleh kedua proses tersebut. Melalui persamaan (4) dapat diketahui nilai akumulasi rata-rata cacat produk dari kedua proses. Jumlah proporsi dari masing-masing proses penyumbang cacat dapat dihitung dengan persamaan (5).

$$
\begin{aligned}
& \sum \text { rata - rata kedua proses } \\
& =\text { rata }- \text { rata }_{1} \\
& + \text { rata }- \text { rata }_{2} \\
& =0.251028 \\
& \text { persentase (\%) } \\
& =\frac{\text { jumlah rata }- \text { rata proses }}{\text { Lrata }- \text { rata kedua proses }}
\end{aligned}
$$

$\%$ proses oven $=\frac{0.089083333}{0.251028}=35 \%$

$\%$ proses creaming $=\frac{0.16194444}{0.251028}=65 \%$

Nilai presentase di atas digambarkan dalam diagram pie pada Gambar 4. Terlihat bahwa proses creaming and pressing (65\%) memberikan kontribusi penyumbang cacat yang lebih besar dibandingkan dengan proses oven and cooling sheet (35\%). Oleh karena itu pemecahan masalah selanjutnya akan difokuskan kepada proses creaming and pressing. 


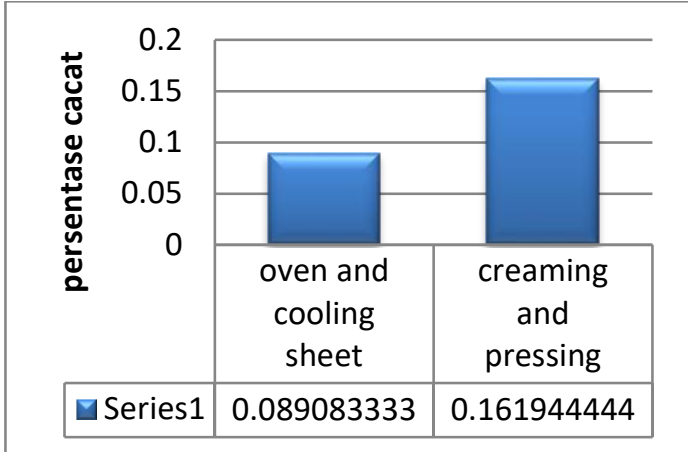

Gambar 3. Perbandingan Rata-Rata

Persentase Cacat Akibat Proses

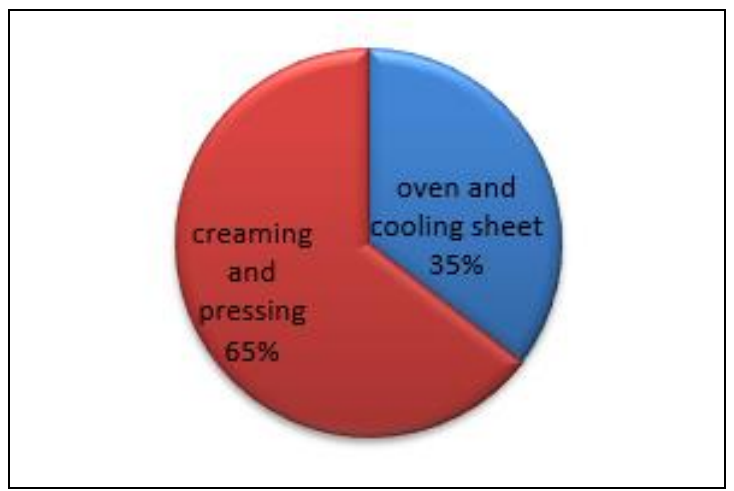

Gambar 4. Diagram Pie Proses

Penyumbang Cacat

\section{Project Statement}

a. Business Case

Perusahaan masih menerima komplain dari customer mengenai adanya produk defect dalam box-box produk yang telah dikirim. Oleh karena itu, proses inspeksi harus ditingkatkan agar produk defect tidak sampai ke tangan customer.

b. Pernyataan Masalah

Besarnya persentase cacat pada produk wafer abon dalam periode Maret 2013 yaitu sebesar 12.55\%. Cacat yang muncul akan menimbulkan kerugian biaya yang harus ditanggung oleh pihak perusahaan yaitu sekitar 360/ pcs.

4. Diagram SIPOC (Suppliers, Input, Processes, Outputs, Customers)

Proses produksi sendiri terdiri dari dari proses pengecekan kualitas bahan baku, penimbangan dan pencampuran bahan baku, pembakaran bahan baku (oven), pemberian pasta, pemotongan, pemeriksaan produk hingga pengemasan produk. Dalam diagram SIPOC akan dijelaskan alur input dan output dari setiap proses produksi yang ada, sebagai berikut:

\section{Proses I}

Supplier: PT. Sriboga Raturaya

Input: Tepung terigu, sagu, minyak, gula, bumbu sapi, dan lain-lain

Process: Bahan baku dari supplier akan diinspeksi kualitasnya, ditimbang dan dicampur oleh bagian Lab perusahaan.

Output: Bahan baku mentah yang sudah tepat takarannya

Customer: Proses Oven and Cooling Sheet

Proses II

Supplier: Proses Oven and Cooling Sheet Input: Kulit wafer yang disebut sheet

Process: Sheet diberikan pasta hingga 3 lapisan kulit sehingga menghasilkan satu ukuran besar wafer abon, lalu dipotongpotong dalam ukuran kecil

Output: Wafer Abon

Customer: Bagian packaging and packing

5. Voice of Customer (VOC)

Salah satu Customer dari produk wafer abon adalah perusahaan produk retail Indomaret, dan kebutuhan customer akan wafer abon adalah:

a. Wafer abon mempunyai ukuran sesuai dengan spesifikasi yang telah diajukan dimana panjang, lebar, dan berat harus sesuai dengan spesifikasi yang ada.

b. Rasa dari wafer abon tidak terlalu manis.

c. Wafer abon mempunyai bentuk fisik yang sesuai dengan spesifikasi yang telah ditentukan (tidak hancur).

d. Wafer abon kuat disimpan hingga tanggal kadarluasa produk yang tercantum pada kemasan.

6. Critical to Quality (CTQ)

Penentuan CTQ ini dilakukan berdasarkan interview yang dilakukan dengan pihak perusahaan, dikemukakan empat kategori CTQ pada produk wafer abon, yaitu: 
a. Penampilan

Kriteria kategori penampilan ditunjukkan dengan tampilan luar dari wafer abon itu sendiri dan teridentifikasi secara visual, seperti keutuhan bagian permukaan wafer abon dan warna.

b. Dimensi

Setiap wafer abon yang diproduksi harus memenuhi spesifikasi dari dimensi yang telah telah ditentukan.

c. Weight

Dari segi weight atau berat, perusahaan harus memastikan berat wafer abon sesuai dengan yang tertera pada kemasan wafer abon.

d. Rasa

Dari segi rasa yang terpenting, wafer abon memberikan rasa yang standar yang sesuai konsisten dengan rasarasa sebelumnya.
Dari keempat jenis CTQ yang dikemukakan oleh pihak perusahaan tersebut, dapat diidentifikasikan jenis-jenis defect yang terjadi pada produk sebagai CTQ potensial penyebab kecacatan pada produk yang diteliti. Dimana dari ke-8 jenis defect ini memiliki karakteristiknya masing-masing dan dapat diidentifikasikan masing-masing perbedaannya pada Tabel 2 .

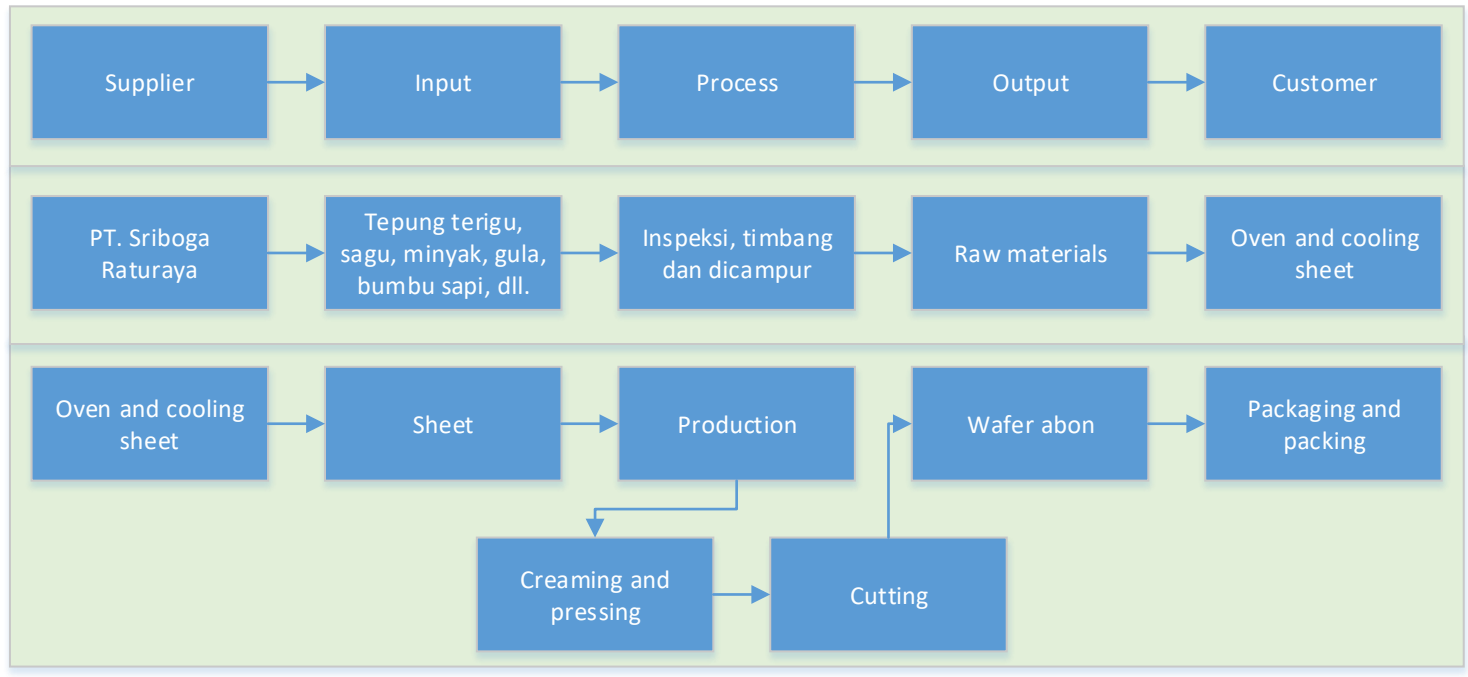

Gambar 5. SIPOC

Tabel 2. Critical to Quality

\begin{tabular}{l|l|l}
\multicolumn{1}{c}{ Kategori Defect } & \multicolumn{1}{c}{ Nama Defect } \\
Critical & 1. Hangus \\
& 2. Mentah \\
& 3. Wafer abon hancur \\
& 4. Sheet Hancur \\
Major & 5. Pasta tidak rata \\
& 6. Retak \\
\hline 7. Pinggiran kulit hancur \\
8. Patah
\end{tabular}




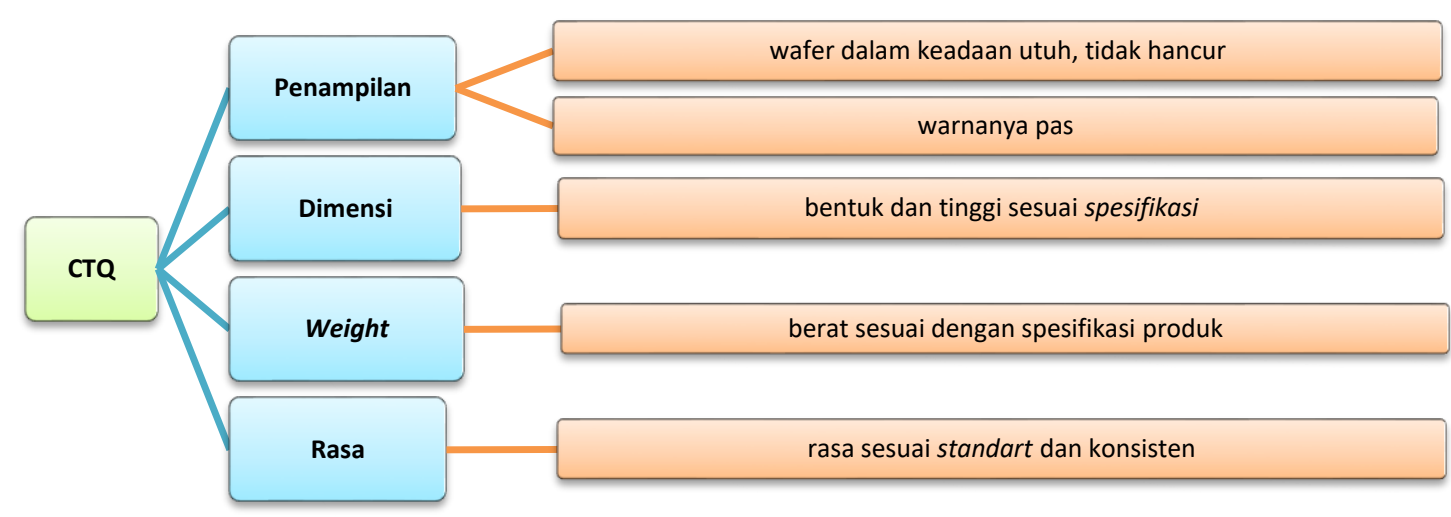

Gambar 6. CTQ Tree

\subsection{Tahap Measure}

1. Perhitungan Biaya Akibat Kualitas Jelek (COPQ)

Berdasarkan data jumlah cacat yang ada pada proses produksi wafer abon, maka dapat dihitung biaya yang ditanggung akibat kualitas jelek berdasarkan:

Jumlah cacat $=1,826$ dus

$=1,826 \times 120 \mathrm{pcs}=219,120 \mathrm{pcs}$

Dari keseluruhan jumlah cacat yang ada, terdapat $17 \%$ dari jumlah keseluruhan cacat yang ada, masih dapat dijual menjadi produk Osuka. Sebesar 83\% dari jumlah cacat keseluruhan yang benarbenar menimbulkan kerugian untuk perusahaan, sehingga jumlah keseluruhan produk yang menimbulkan kerugian adalah seperti perhitungan dibawah ini:

Jumlah cacat $=219,120$,

$=219,120 \times 83 \%=181,869.6 \mathrm{pcs}$

$=181,870 \mathrm{pcs}$

Biaya satuan $=$ Rp. 360,-

COPQ = Biaya satuan $x$ Jumlah cacat

$=$ Rp. $360,-x 181,870=$ Rp. $65,473,200,-$

Jadi biaya yang harus dikeluarkan oleh pihak perusahaan akibat adanya produk yang jelek selama bulan Maret 2013 adalah sebesar Rp. 65,473,200,-

2. Pembuatan Peta Control P

Pembuatan peta control berguna untuk dalam batas pengendalian atau belum. Berdasarkan data historis perusahaan yaitu data jumlah produksi dan data jumlah defect dari produk wafer abon yang merupakan data atribut dan mempunyai jumlah sampel yang berbeda pada setiap pendataannya sehingga pemetaan peta kontrol dilakukan dengan peta kontrol $P$. Tabel 3 menunjukkan adalah data cacat produk wafer abon pada bulan Mei 2013.

Tabel 3. Persentase Cacat Bulan Mei 2013Wafer Abon

\begin{tabular}{|c|r|r|r|}
\hline $\begin{array}{c}\text { Data } \\
\text { ke }\end{array}$ & $\begin{array}{c}\text { Jumlah } \\
\text { Produksi } \\
\text { (dalam } \\
\text { dus) }\end{array}$ & $\begin{array}{c}\text { Jumlah } \\
\text { Defect } \\
\text { (dalam } \\
\text { dus) }\end{array}$ & Proporsi \\
\hline 1 & 672 & 110 & 0.163690 \\
\hline 2 & 1116 & 210 & 0.188172 \\
\hline 3 & 302 & 50 & 0.165563 \\
\hline 4 & 920 & 165 & 0.179348 \\
\hline 5 & 448 & 51 & 0.113839 \\
\hline 6 & 917 & 113 & 0.123228 \\
\hline 7 & 1133 & 161 & 0.142101 \\
\hline 8 & 572 & 57 & 0.099650 \\
\hline 9 & 397 & 40 & 0.100756 \\
\hline 10 & 357 & 25 & 0.070028 \\
\hline 11 & 543 & 100 & 0.184162 \\
\hline 12 & 678 & 87 & 0.128319 \\
\hline 13 & 541 & 52 & 0.096118 \\
\hline 14 & 548 & 47 & 0.085766 \\
\hline 15 & 772 & 107 & 0.138601 \\
\hline 16 & 795 & 84 & 0.105660 \\
\hline 17 & 1098 & 70 & 0.063752 \\
\hline 18 & 1181 & 78 & 0.066046 \\
\hline 19 & 520 & 79 & 0.151923 \\
\hline 20 & 871 & 140 & 0.160735 \\
\hline Total & $\mathbf{1 4 3 8 1}$ & $\mathbf{1 8 2 6}$ & \\
& & &
\end{tabular}


Perhitungan proporsi dihitung dengan menggunakan persamaan (6).

Proporsi data ke $-1\left(P_{1}\right)=\frac{J D}{J P}$

dimana:

JD = Jumlah defect

$\mathrm{JP}=$ Jumlah produksi

$P_{1}=\frac{110}{672}=0.16369$

Berikut ini adalah hasil perhitungan Upper Control Limit (UCL) dan Lower Control Limit (LCL) dengan menggunakan software microsoft excel dan Minitab 16:

$C L=\bar{P}=\frac{\sum P_{n}}{n}=\frac{1826}{14381}=0.126973$

$U C L=\bar{P}+3 \sqrt{\frac{\bar{P}(1-\bar{P})}{n}}=0.165504$

$L C L=\bar{P}-3 \sqrt{\frac{\bar{P}(1-\bar{P})}{n}}=0.088442$

Dari Gambar 7 dapat dilihat bahwa terdapat 6 data yang berada di luar batas spesifikasi yang ditentukan, dapat disimpulkan bahwa peta kendali berada pada luar pengendalian statistik yang disebabkan bervariasinya persentase defect yang terjadi. Revisi dilakukan untuk mengetahui kapabilitas proses produksi produk yang terkontrol dengan mengeliminasi data-data yang berada pada luar batas atas spesifikasi. Batas bawah spesifikasi tidak dieliminasi dikarenakan permintaan dari pihak perusahaan yang ingin modifikasi peta kontrol $P$. Alasan yang diberikan oleh perusahaan adalah jumlah data yang terjadi diluar batas bawah peta kontrol $\mathrm{P}$ merupakan suatu prestasi karena mampu menahan jumlah defect pada nilai yang rendah. Oleh karena itu, hanya 3 data yang keluar dari batas spesifikasi yang akan dieliminasi.
Pada peta kontrol revisi 1 seperti terlihat pada Gambar 8 proses produksi belum berada dalam keadaan stabil dikarenakan masih terdapat data yang berada diluar batas kendali atas spesifikasi. Oleh karena itu akan dilakukan revisi sampai tidak ada data yang keluar dari batas atas spesifikasi. Proses produksi stabil setelah dilakukan revisi kelima. Grafik revisirevisi tersebut dapat dilihat pada Gambar 8, Gambar 9, Gambar 10 dan Gambar 11.

Pada peta kontrol revisi 5 proses produksi berada dalam keadaan stabil dengan tidak ada data proporsi yang berada di luar batas pengendalian. Didapatkan nilai $\overline{\mathrm{P}}_{\text {revisi }}=0.08489 ; \mathrm{UCL}=0.10922 ; \mathrm{LCL}=$ 0.06056. Dapat dilihat pada Gambar 12 yang menunjukkan data berada dalam batas spesifikasi dan dapat dihitung kapabilitas prosesnya.

3. Perhitungan Capability Process

Perhitungan kapabilitas proses dilakukan pada peta kendali $\mathrm{P}$ yang telah dilakukan revisi dimana berdasarkan hasil perhitungan didapat nilai $\overline{\mathrm{P}}_{\text {revisi }}=$ 0.08489. Maka nilai kapabilitas proses $(C p)$ adalah:

$C p=1-\overline{\mathrm{P}}=1-0.08489=0.91511$

Dalam proses terkendali kapabilitas proses mencapai nilai sebesar $91.51 \%$, dimana kurang dari satu yang merupakan nilai yang kurang baik sehingga perlu dilakukan pengendalian. 
ISSN: 1979-1720 Journal of Industrial Engineering and Management Systems

Vol. 10, No. 1, February 2017

Tabel 4. Perhitungan P Control Chart

\begin{tabular}{|c|r|r|r|c|c|c|}
\hline Data ke & Produksi & Cacat & Proporsi & LCL & CL & UCL \\
\hline 1 & 672 & 110 & 0.16369 & 0.088442 & 0.126973 & 0.165504 \\
\hline 2 & 1116 & 210 & 0.188172 & 0.097074 & 0.126973 & 0.156872 \\
\hline 3 & 302 & 50 & 0.165563 & 0.069497 & 0.126973 & 0.184449 \\
\hline 4 & 920 & 165 & 0.179348 & 0.094043 & 0.126973 & 0.159903 \\
\hline 5 & 448 & 51 & 0.113839 & 0.079783 & 0.126973 & 0.174163 \\
\hline 6 & 917 & 113 & 0.123228 & 0.093989 & 0.126973 & 0.159957 \\
\hline 7 & 1133 & 161 & 0.142101 & 0.097299 & 0.126973 & 0.156647 \\
\hline 8 & 572 & 57 & 0.099650 & 0.085210 & 0.126973 & 0.168736 \\
\hline 9 & 397 & 40 & 0.100756 & 0.076843 & 0.126973 & 0.177103 \\
\hline 10 & 357 & 25 & 0.070028 & 0.074109 & 0.126973 & 0.179837 \\
\hline 11 & 543 & 100 & 0.184162 & 0.084109 & 0.126973 & 0.169837 \\
\hline 12 & 678 & 87 & 0.128319 & 0.088613 & 0.126973 & 0.165333 \\
\hline 13 & 541 & 52 & 0.096118 & 0.084030 & 0.126973 & 0.169916 \\
\hline 14 & 548 & 47 & 0.085766 & 0.084305 & 0.126973 & 0.169641 \\
\hline 15 & 772 & 107 & 0.138601 & 0.091024 & 0.126973 & 0.162922 \\
\hline 16 & 795 & 84 & 0.105660 & 0.091548 & 0.126973 & 0.162398 \\
\hline 17 & 1098 & 70 & 0.063752 & 0.096830 & 0.126973 & 0.157116 \\
\hline 18 & 1181 & 78 & 0.066046 & 0.097908 & 0.126973 & 0.156038 \\
\hline 19 & 520 & 79 & 0.151923 & 0.083172 & 0.126973 & 0.170775 \\
\hline 20 & 871 & 140 & 0.160735 & 0.093129 & 0.126973 & 0.160817 \\
\hline Total & 14381 & 1826 & \multicolumn{5}{|c}{} &
\end{tabular}

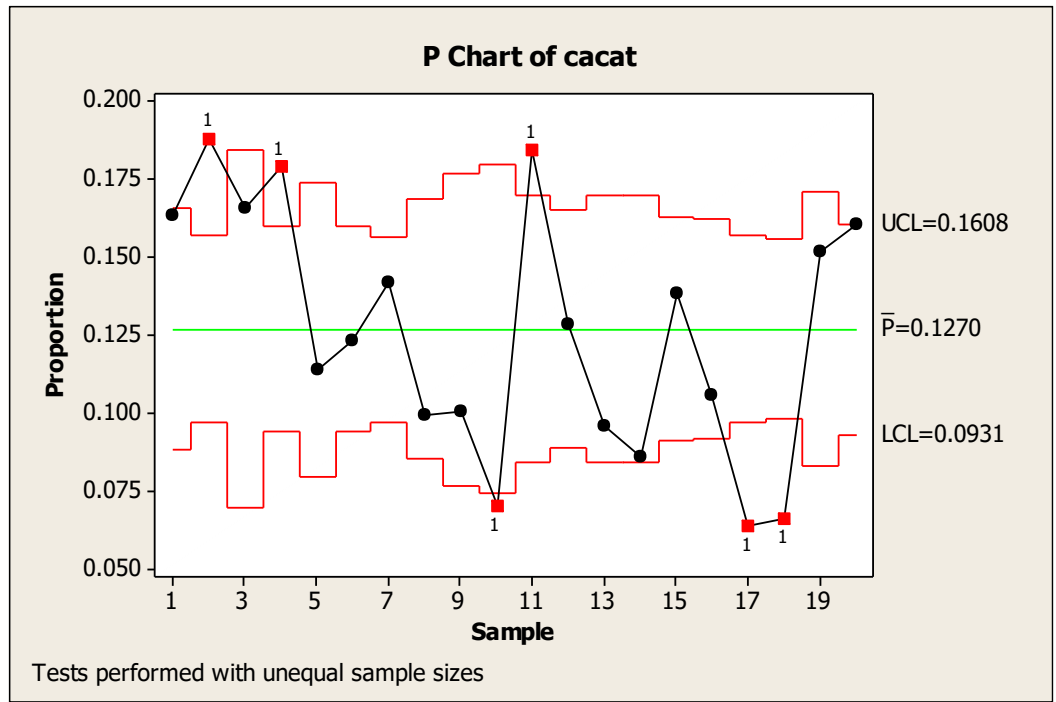

Gambar 7. P-Chart Cacat Produk Wafer Abon 


\section{JIEMS}

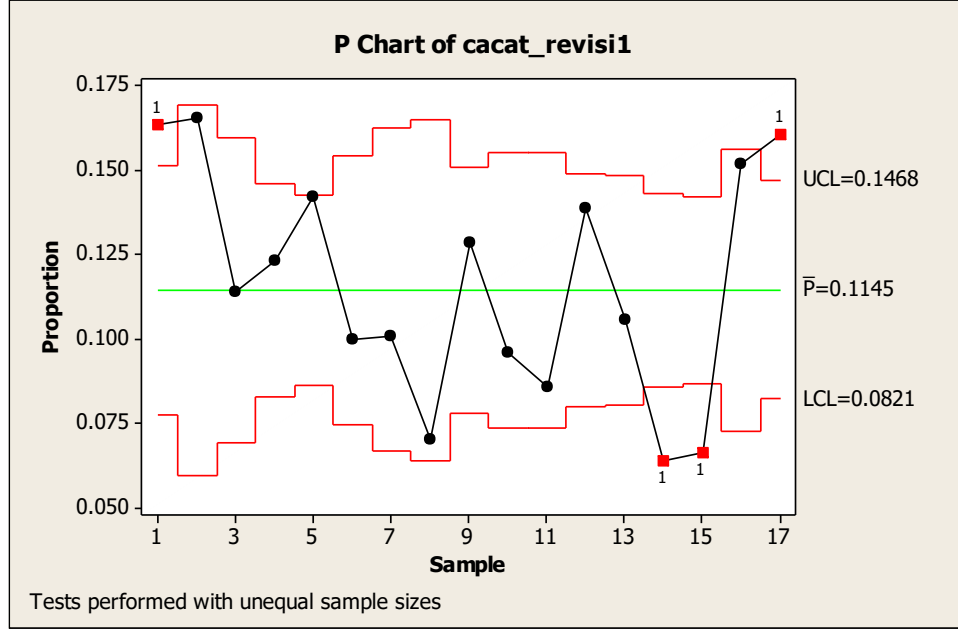

Gambar 8. P-Chart Cacat Produk Wafer Abon (Revisi 1)

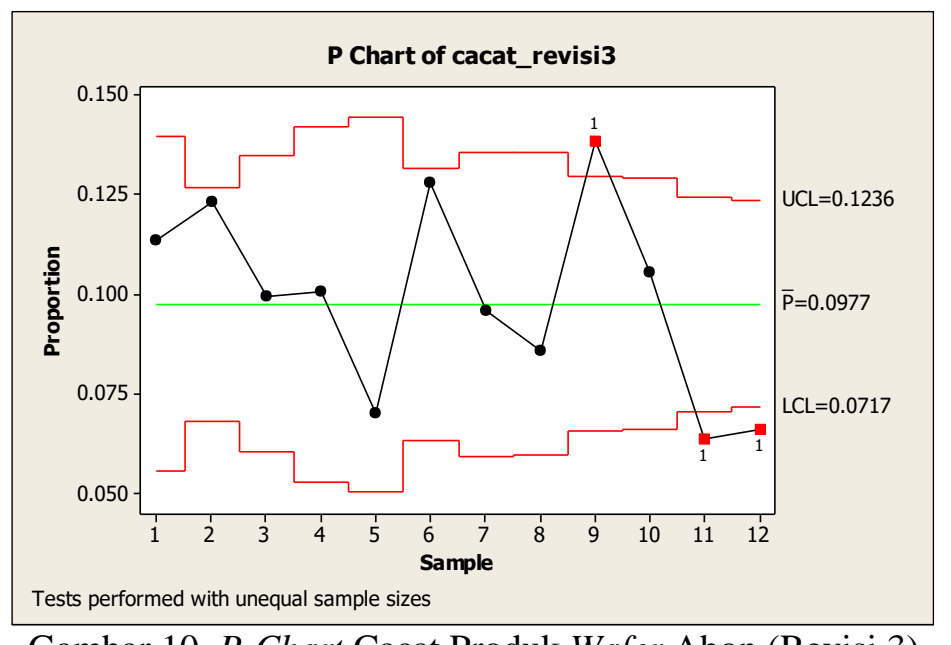

Gambar 10. P-Chart Cacat Produk Wafer Abon (Revisi 3)

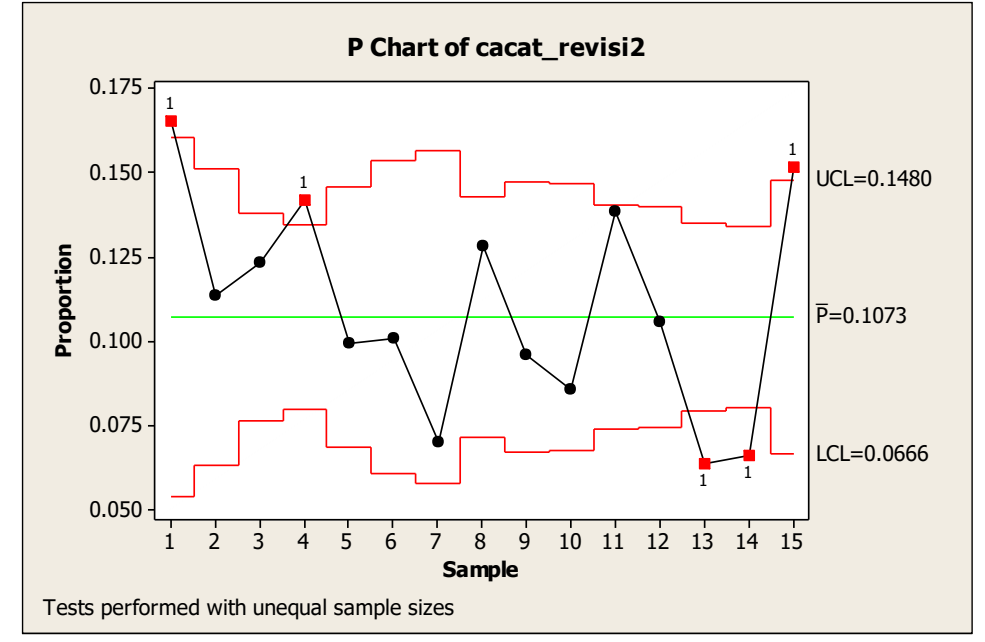

Gambar 9. P-Chart Cacat Produk Wafer Abon (Revisi 2)

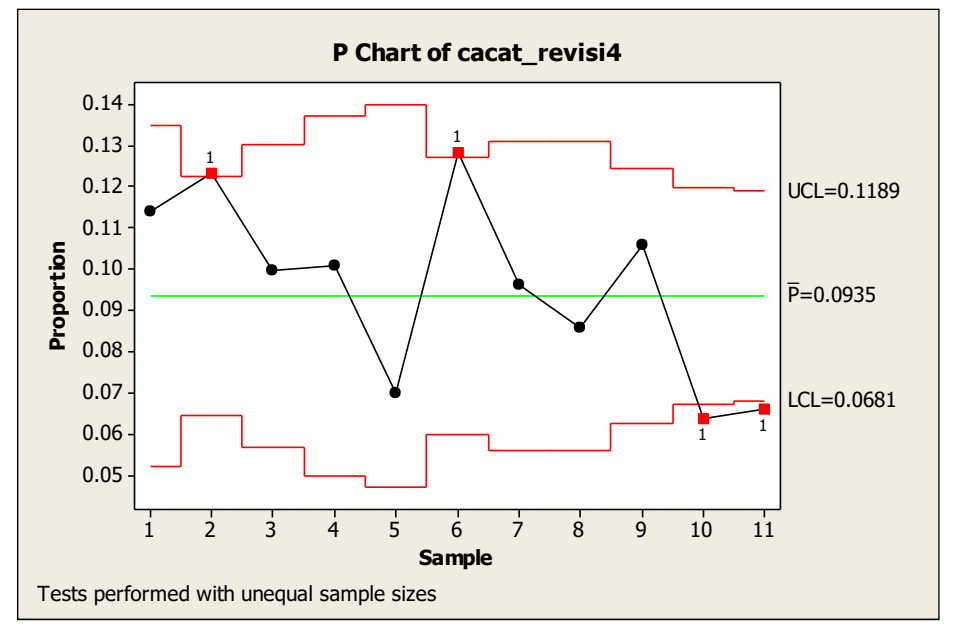

Gambar 11. P-Chart Cacat Produk Wafer Abon (Revisi 4) 


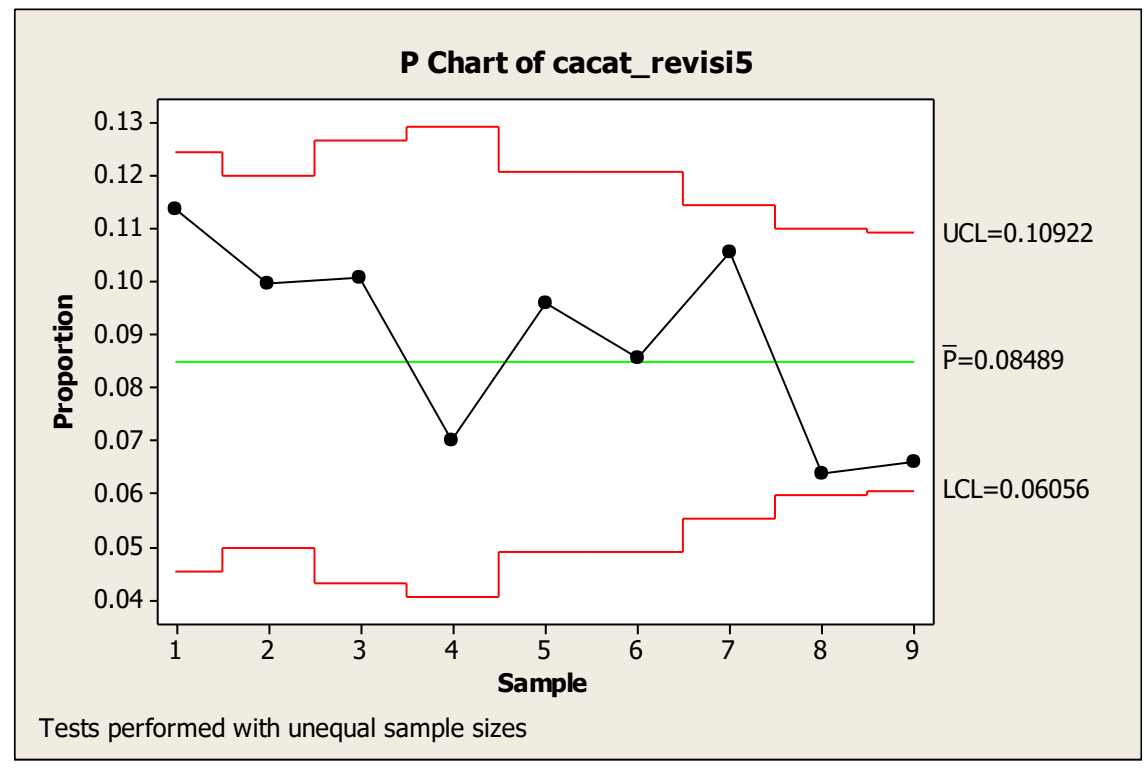

Gambar 12. P-Chart Cacat Produk Wafer Abon (Revisi 5)

4. Perhitungan DPMO dan Level Sigma Perhitungan DPMO dan level sigma dilakukan dengan langkah-langkah sebagai berikut:

a. Unit

Jumlah produk wafer abon yang diinspeksi selama periode produksi (Maret 2013) adalah sebanyak 14,381 dus. Dimana satu dus berisi 120 buah, jadi total jumlah produk wafer adalah $14,381 \times 120=1,725,720$.

b. Opportunities

Terdapat 8 karakteristik cacat yang dipilih sebagai CTQ penyebab potensial kegagalan produk yang dapat dilihat pada Tabel 2.

c. Defect

Banyaknya defect produk wafer abon yang terjadi pada proses inspeksi selama 1 bulan produksi adalah sebanyak 1,826 dus, dan bila dikonversi dalam jumlah produk sejumlah 219,120 buah dari jumlah total produksi sebanyak $1,725,720$.

d. Defect Per Unit

Nilai Defect Per Unit dapat dihitung: $D P U=\frac{D}{U}=\frac{219120}{1725720}=0.12697$

e. Total Opportunities (TOP)

TOP $=\mathrm{U} \times \mathrm{OP}=1,725,720 \times 8=$ $13,805,760$ f. Defect Per Opportunities (DPO)

$$
\begin{aligned}
& D P O=\frac{D}{T O P}=\frac{219120}{13805760} \\
& =0.0158716
\end{aligned}
$$

g. Defect Per Million Opportunities (DPMO)

$\mathrm{DPMO}=\mathrm{DPO} \times 1,000,000$

$$
=0.0158716 \times 1,000,000=15,871.64
$$

h. Sigma Level (Tingkat Sigma)

Tingkat Sigma $=$ normsinv $\left(\frac{1000000-D P M O}{1000000}\right)+1.5=$ 3.65

Tabel 5. Six Sigma Calculator

\begin{tabular}{|l|r|l|r|}
\hline $\begin{array}{l}\text { A. All values required to calculate Sigma } \\
\text { level }\end{array}$ \\
\hline Defects: & 219,120 & DPMO: & 15,872 \\
\hline Units: & $1,725,720$ & $\begin{array}{l}\text { Sigma } \\
\text { Level }\end{array}$ & 3.65 \\
\hline $\begin{array}{l}\text { Opportunit } \\
\text { ies per } \\
\text { Unit: }\end{array}$ & 8 & & \\
\hline $\begin{array}{l}\text { B. Enter only the known Defects Per } \\
\text { Million Opportunities }\end{array}$ \\
\begin{tabular}{l|l|l|r|} 
Enter \\
DPMO
\end{tabular} & 15,872 & $\begin{array}{l}\text { Sigma } \\
\text { Level }\end{array}$ & 3.65 \\
\hline
\end{tabular}

Dari hasil perhitungan tingkat sigma didapatkan nilai sigma sebesar 3.65 untuk produk wafer abon yang diteliti. Nilai sigma masih jauh untuk mencapai nilai sigma sempurna yaitu 6 , sehingga masih perlu 
dilakukan identifikasi dan analisis penyebab proses yang menyebabkan produk defect.

\subsection{Tahap Analyze}

1. Analisis cacat dominan

Berdasarkan data yang didapatkan jumlah cacat produk ditampilkan pada Tabel 6.

Tabel 6. Jumlah Jenis Defect

\begin{tabular}{|l|r|r|r|}
\hline $\begin{array}{c}\text { Jenis } \\
\text { Defect }\end{array}$ & $\begin{array}{c}\text { Jumlah } \\
\text { Defect }\end{array}$ & Persentase & $\begin{array}{l}\text { Persentase } \\
\text { Kumulatif }\end{array}$ \\
\hline $\begin{array}{l}\text { Pasta } \\
\text { tidak } \\
\text { rata }\end{array}$ & 313 & 0.536878 & 0.536878 \\
\hline $\begin{array}{l}\text { Hancur } \\
\text { pinggir }\end{array}$ & 95 & 0.16295 & 0.699828 \\
\hline Retak & 94 & 0.161235 & 0.861063 \\
\hline Patah & 50 & 0.085763 & 0.946827 \\
\hline Hancur & 31 & 0.053173 & 1 \\
\hline Mentah & 0 & 0 & 1 \\
\hline Hangus & 0 & 0 & 1 \\
\hline $\begin{array}{l}\text { Jumlah } \\
\text { Defect }\end{array}$ & 583 & 1.0000 & \\
\hline
\end{tabular}

Dari diagram pareto pada Gambar 3 dapat diketahui jenis-jenis defect yang paling dominan yang mewakili masingmasing kategori dengan melihat nilai kumulatifnya. Sesuai dengan prinsip pareto yang menyatakan aturan $80 / 20$ yang artinya 80 persen masalah kualitas disebabkan oleh 20 persen penyebab kecacatan, sehingga dipilih jenis-jenis defect dengan kumulatif mencapai $80 \%$ dengan asumsi bahwa dengan $80 \%$ tersebut dapat mewakili seluruh jenis defect yang terjadi. Dapat dilihat bahwa untuk defect dominan yang ada pada jenis defect pasta tidak rata $(53.7 \%)$, hancur pinggir (16.3\%), retak (16.1\%). Ketiga jenis defect tersebut akan dijadikan prioritas dalam penanganan masalah.

2. Menentukan Akar Permasalahan dengan Diagram Sebab Akibat (Fishbone Diagram) dan Diagram Five Whys.

Diagram Sebab Akibat dibuat untuk mengidentifikasikan penyebab terjadinya defect berdasarkan lima kategori faktor penyebab yaitu Man, Machine, Method, Material dan Environment. Sedangkan diagram Five Whys dibuat untuk mengetahui akar penyebab masalah terjadinya defect itu sendiri dengan pertanyaan mengapa pada setiap penyebab yang teridentifikasi hingga akar penyebab masalah ditemukan.

Tabel 7. Brainstorming Penyebab Defect Pasta Tidak Rata

Penyebab: Setelan mesin tidak sesuai Faktor Penyebab: Method, Man

1. Setelan setting mesin yang berubah-ubah, terlalu tinggi atau terlalu rendah dari kedudukan conveyor sehingga pasta yang dioleskan tidak rata, kadang tebal kadang tipis.

Penyebab: Pasta yang telalu kental

Faktor Penyebab: Method, Man

2. Adonan pasta yang terlalu kental atau terlalu padat juga dapat mengakibatkan pengolesan pasta tidak rata, pasta akan cenderung menggumpal dan hanya terolesi di beberapa bagian wafer saja.

Penyebab: Pasta terlalu encer Faktor Penyebab: Method, Man

3. Adonan pasta yang terlalu encer atau terlalu cair juga dapat mengakibatkan pengolesan pasta tidak rata, pasta akan cenderung menetes dari mesin creaming sehingga ketebalan pasta tidak merata dan akan merusak sheet dari wafer abon.

Penyebab: Mesin creaming yang bocor samping

Faktor Penyebab: Method, Man, Machine

4. Bagian samping dari mesin yang longgar mengakibatkan kebocoran dari pasta, sehingga pasta jatuh-jatuh ke sheet dan mengakibatkan ketebalan pasta yang tidak merata.

Tabel 8. Brainstorming Penyebab Defect Hancur Pinggir

Penyebab: Sheet terlalu tipis

Faktor Penyebab: Method, Man

1. Setelan adonan pada mesin oven yang terlalu sedikit, membuat sheet terlalu tipis dan mencerung mudah hancur, terutama bagian pinggir dari sheet, sehingga biar hanya berbenturan sedikit sudah membuat sheet hancur pada bagian pinggirnya.

Penyebab: Terjepit pada proses cooling sheet

Faktor Penyebab: Machine, Method

2. Ukuran sheet yang terlalu melebar mengakibatkan bagian pinggir. Bagian pinggir menjadi bagian yang rentan 
hancur dikarenakan mudah terjepit saat proses cooling sheet. Sheet yang terjepit pasti mengalami hancur pinggir sebelum menuju proses creaming.

Penyebab: Inkonsistenan pada mesin oven Faktor Penyebab: Method, Man, Machine, Environment

3. Mesin yang berjalan tidak konsisten juga menjadi penyebab dari hancur pinggir sheet dari wafer abon. Saat memasuki jam-jam tertentu yang dimana suhu meningkat, membuat mesin akan lebih tidak stabil yang mengakibatkan cetakan sheet yang hancur dibagian pinggirnya, hanya terbentuk bagian tengah saja.

4. Suhu yang meningkat, terutama siang hari membuat cetakan loyang dari sheet mengalami pemuaian sehingga tidak secara rapat menekan adonan sheet, mengakibatkan adonan hanya mengumpul di tengah dan tidak merata pada bagian samping.

Penyebab: Mesin creaming yang kotor Faktor Penyebab: Method, Man, Machine

5. Bagian samping dari mesin creaming yang kotor akibat pasta yang menetes, menghambat laju dari sheet, sehingga seringkali sheet yang terhambat mengalami hancur pada bagian pinggir.
Tabel 9. Brainstorming Penyebab Defect Retak

Penyebab: Sheet menempel pada loyang

Faktor Penyebab: Method, Man

1. Sheet yang menempel pada loyang secara otomatis tidak dapat keluar langsung dari oven, perlu bantuan operator untuk mencungkilnya dengan pengait. Semakin kuat menempel, maka cungkilan dari operator akan semakin kuat dan mengakibatkan keretakan akibat cungkilan.

2. Loyang yang terlalu kering (kurang minyak) juga menjadi penyebab sheet menempel dan tidak mudah lepas dari loyang secara otomatis.

Penyebab: Sheet terlalu tipis

\section{Faktor Penyebab: Method, Man}

3. Setelan adonan pada mesin oven yang terlalu sedikit, membuat sheet terlalu tipis dan mencerung mudah hancur, terutama bagian pinggir dari sheet, sehingga biar hanya berbenturan sedikit sudah membuat sheet hancur pada bagian pinggirnya. Sehingga hanya benturan sedikit mengakibatkan sheet cenderung retak.

4. Pada saat creaming dilakukan sheet yang terlalu tipis akan mudah retak saat dilakukan proses penumpukan menjadi wafer.

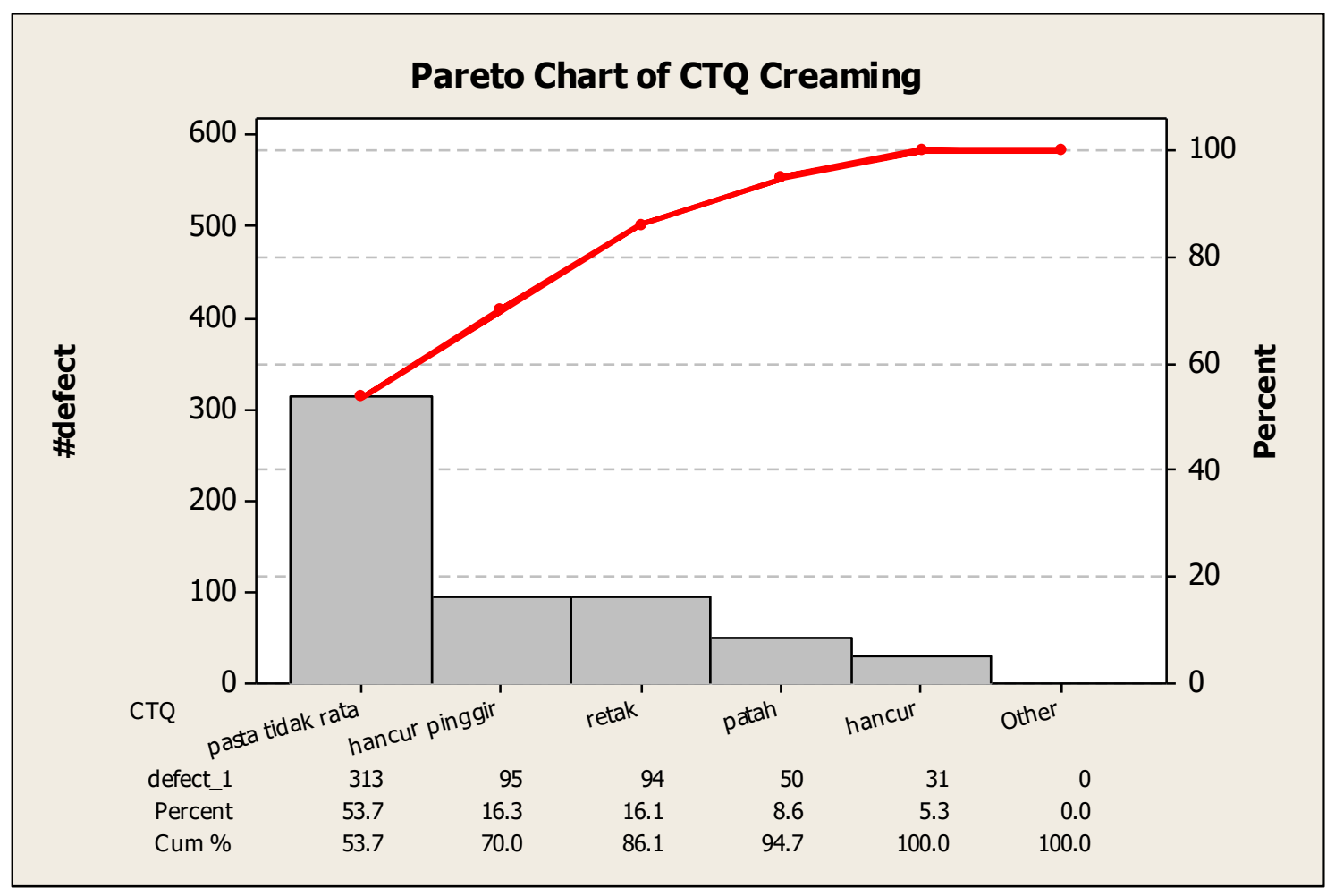

Gambar 13. Diagram Pareto CTQ Creaming 
ISSN: 1979-1720 Journal of Industrial Engineering and Management Systems

Vol. 10, No. 1, February 2017

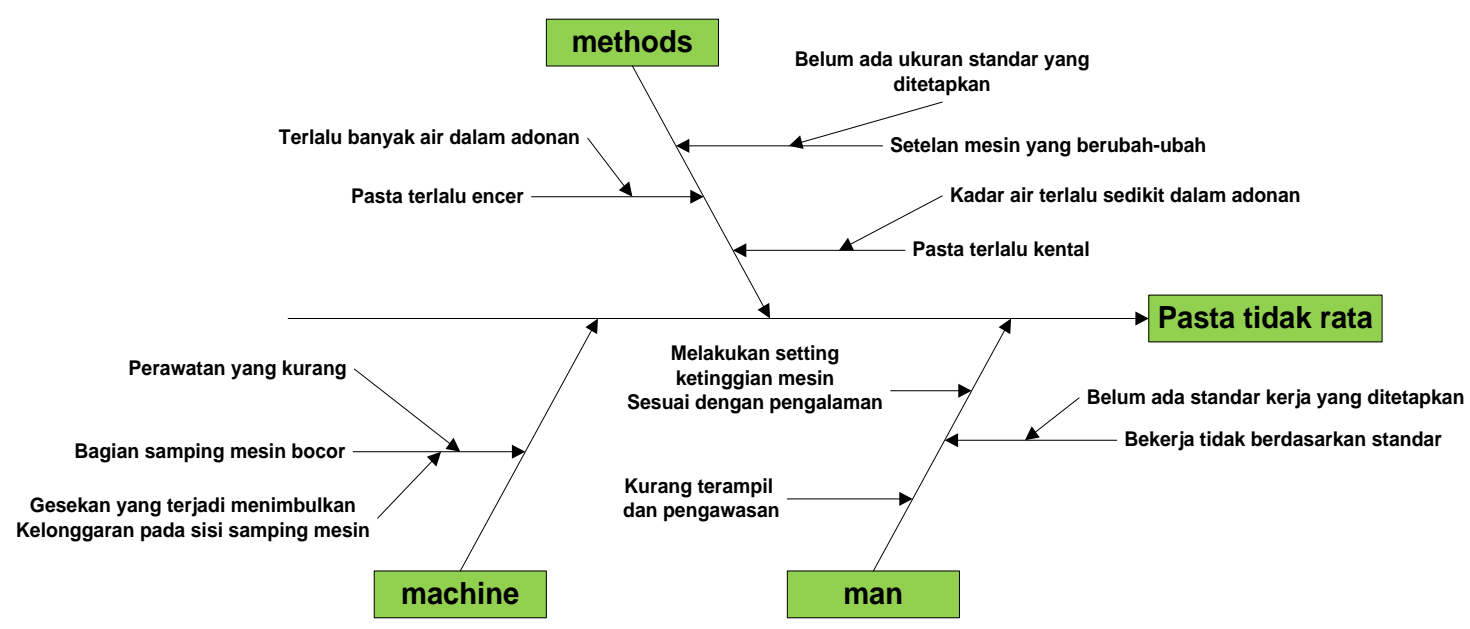

Gambar 14. Diagram Cause and Effect Defect Pasta Tidak Rata

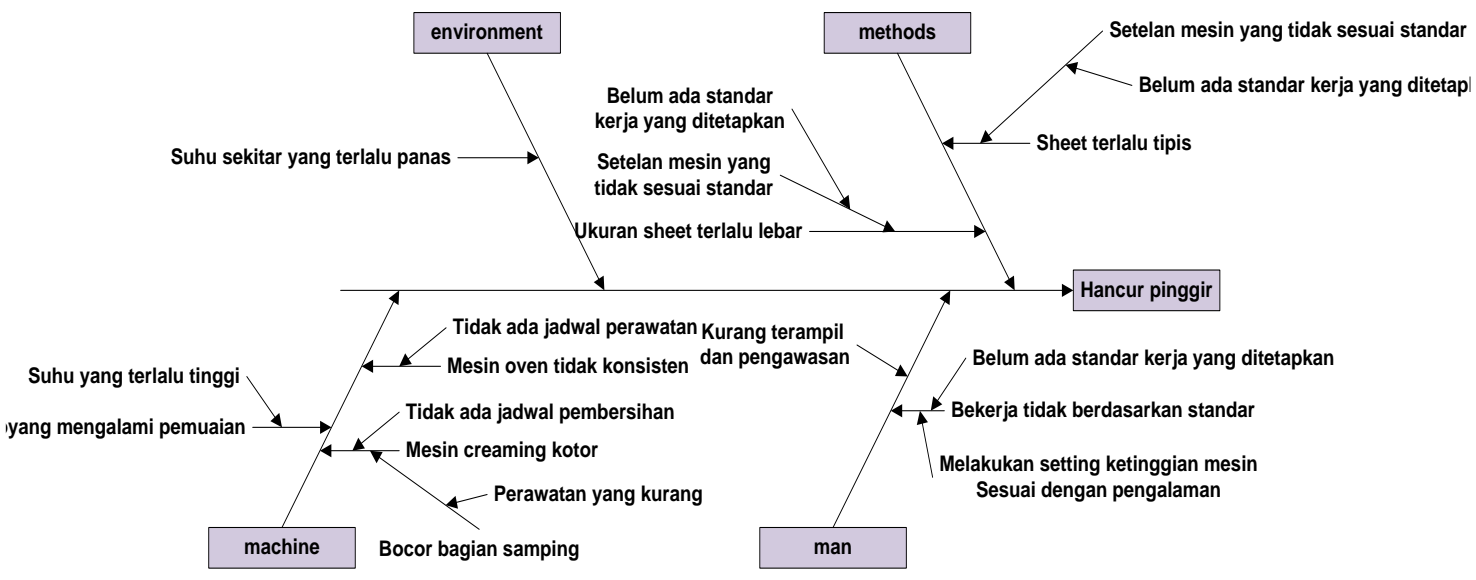

Gambar 15. Diagram Cause and Effect Defect Hancur Pinggir

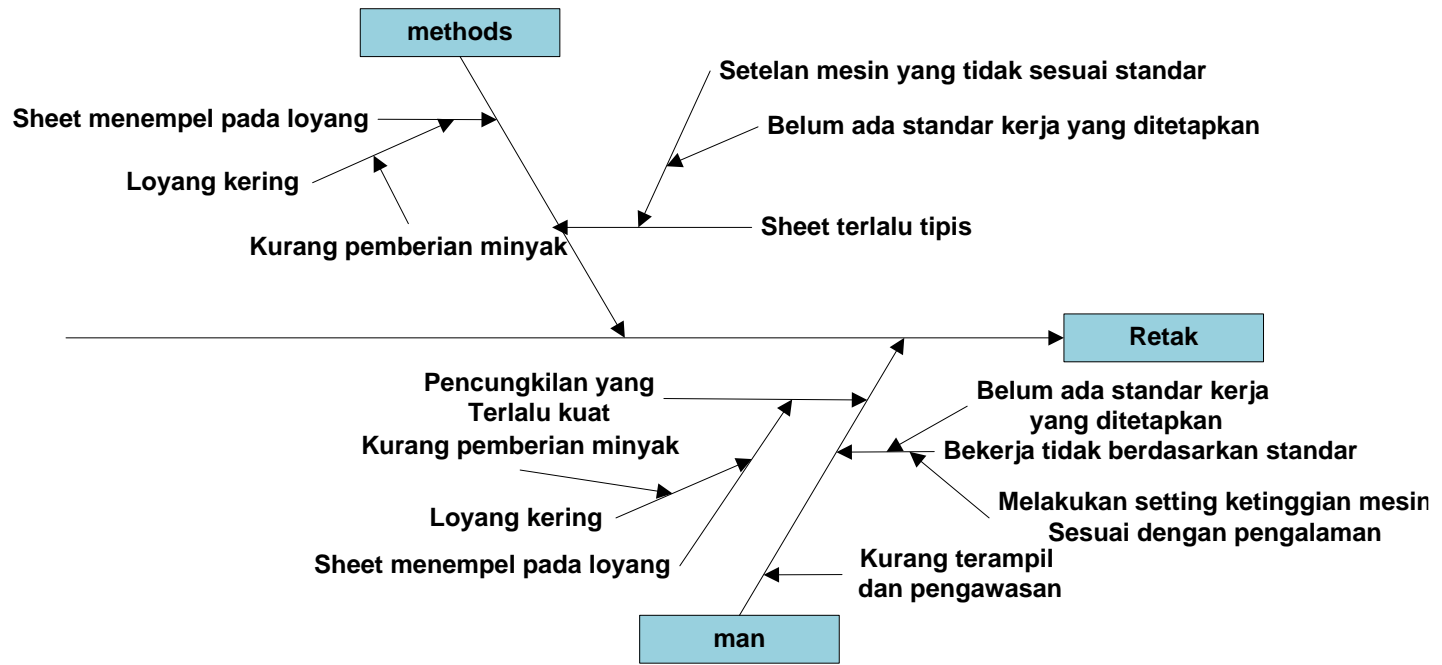

Gambar 16. Diagram Cause and Effect Defect Retak 
ISSN: 1979-1720 Journal of Industrial Engineering and Management Systems

Vol. 10, No. 1, February 2017

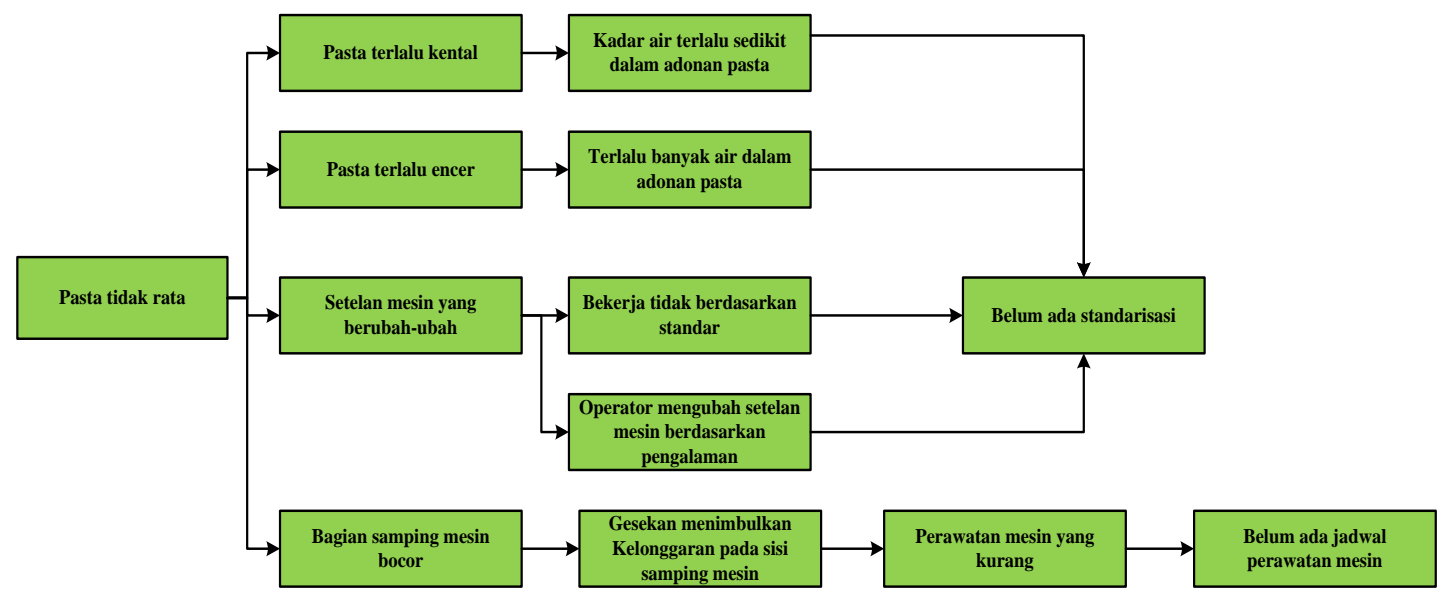

Gambar 17. Diagram Five Whys Defect Pasta Tidak Rata

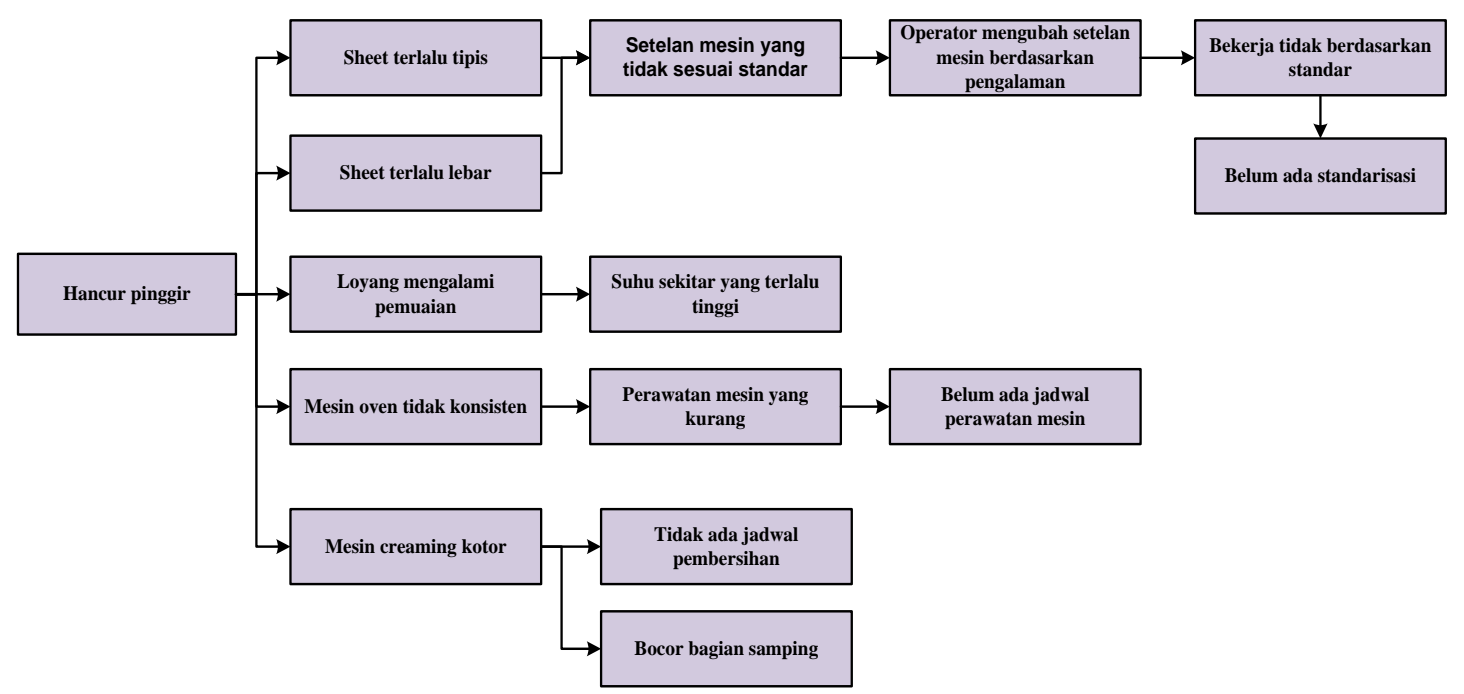

Gambar 18. Diagram Five Whys Defect Hancur Pinggir

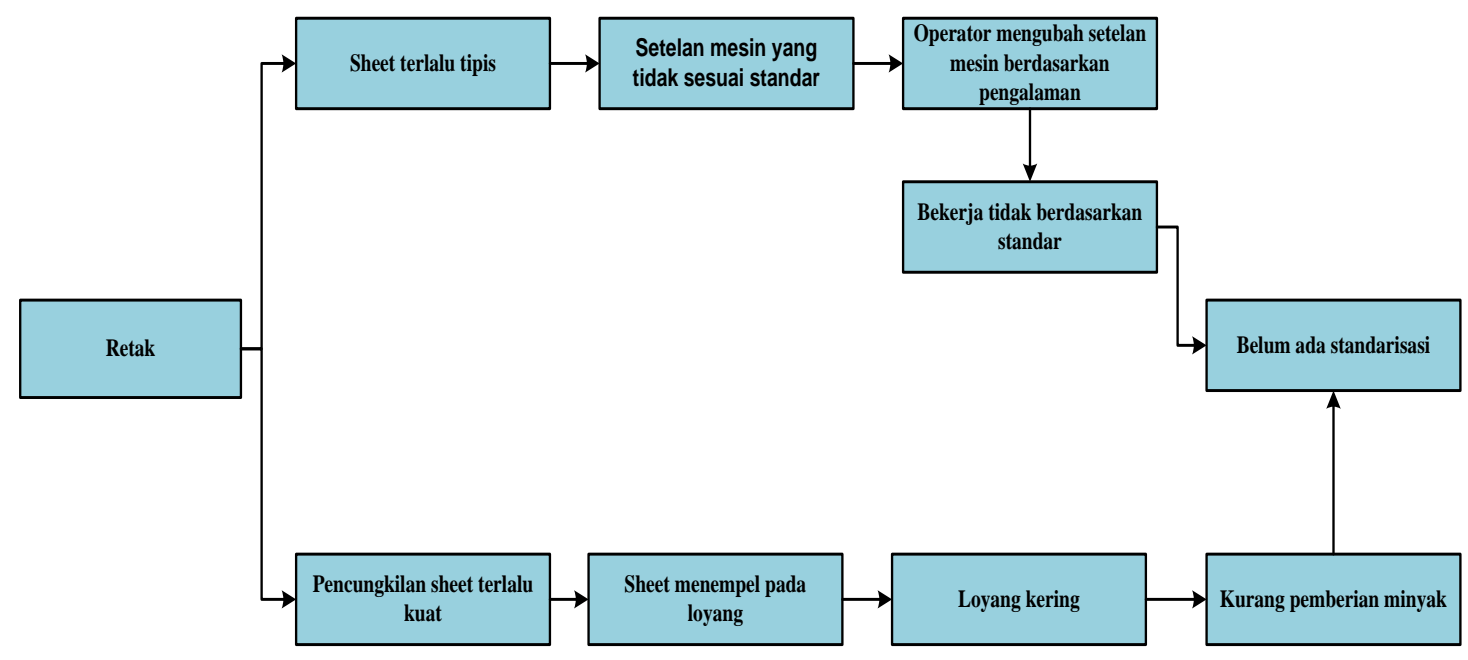

Gambar 19. Diagram Five Whys Defect Retak 


\subsection{Tahap Improve}

1. Uraian usulan perbaikan pada modus kegagalan faktor method.

a. Pembuatan standar ketinggian mesin creaming

Pembuatan standar ketinggian mesin creaming penting karena menentukan tebal tipisnya pasta yang diolesi. Selama dilakukannya pengamatan, tidak terdapat ukuran standar untuk ketinggian mesin, operator melakukan penyetelan sesuai dengan penilaian mereka dan sesuai dengan pengalaman mereka.

b. Pemberian minyak secara berkala Keadaan loyang yang kering mengakibatkan adonan sheet menempel pada loyang dan tidak dapat keluar secara otomatis. Sheet yang menempel terlalu kuat maka membutuhkan cungkilan yang kuat pula, ini mengakibatkan sheet retak dan beberapa menjadi hancur. Oleh karena itu pemberian atau pengolesan minyak kepada loyang sangat diperlukan.

c. Pembersihan mesin creaming secara berkala

Akibat tetesan-tetesan pasta dari mesin creaming, mengakibatkan sisisisi dari mesin creaming menjadi kotor dan dipenuhi oleh pasta. Hal ini dapat menghambat laju dari sheet dari proses sebelumnya. Bila semakin menumpuk tetesan pasta tersebut dapat membuat sheet hancur pada bagian pinggir karena berbenturan pada bagian samping.

2. Uraian usulan perbaikan pada modus kegagalan faktor machine.

a. Membuat jadwal dan instruksi perawatan mesin oven.

Pembuatan jadwal dan instruksi perawatan pada mesin oven dibutuhkan karena mesin oven merupakan awal dari sheet terbentuk. Bila barang yang dihasilkan pada proses ini jelek maka proses selanjutnya juga akan menghasilkan barang yang jelek pula.

b. Menambah blower atau kipas angin sebagai pendingin.
Suhu yang begitu tinggi membuat loyang memuai. Loyang yang memuai membuat cetakan tidak tertekan sempurna, sehingga hasil cetakan pun tidak sempurna. Oleh karena disarankan untuk penambahan satu kipas blower yang berguna sebagai pendingin agar suhu dapat diturunkan dan pemuaian loyang dapat dicegah.

c. Melakukan jadwal perawatan dan pembetulan untuk mesin creaming yang mengalami kebocoran samping. Pada saat dilakukannya pengamatan, terdapat kebocoran pada bagian samping mesin creaming. Perbaikan perlu dilakukan guna mencegah kebocoran yang terjadi.

3. Rencana Implementasi Perbaikan Membuat spesifikasi standart yang jelas mengenai setelan mesin oven dan mesin creaming

Merancang kembali setelan untuk mesin oven dan mesin creaming guna mendapatkan setelan yang sesuai dengan spesifikasi yang diinginkan. Percobaan setelan terbaik dapat dilakukan trial terlebih dahulu, untuk dapat melihat mana setelan yang paling pas dengan spesifikasi yang dibutuhkan.

Tabel 10. Alternatif Perbaikan pada Modus Kegagalan Faktor Method

\begin{tabular}{|l|l|}
\hline \multicolumn{1}{|c|}{$\begin{array}{c}\text { Modus } \\
\text { Pogagalan }\end{array}$} & \multicolumn{1}{|c|}{ Pengendalian } \\
\hline $\begin{array}{l}\text { Setelan mesin } \\
\text { tidak sesuai }\end{array}$ & $\begin{array}{l}\text { Pembuatan standar setelan } \\
\text { ketinggian mesin creaming, } \\
\text { yang paling sesuai dengan } \\
\text { standar yang diperlukan. }\end{array}$ \\
\hline $\begin{array}{l}\text { Sheet yang } \\
\text { menempel } \\
\text { dengan } \\
\text { loyang }\end{array}$ & $\begin{array}{l}\text { Pemberian minyak secara } \\
\text { berkala, misalnya pada saat } \\
\text { sudah mulai terdapat } \\
\text { kecenderungan sheet } \\
\text { menempel }\end{array}$ \\
\hline $\begin{array}{l}\text { Mesin } \\
\text { creaming } \\
\text { kotor, } \\
\text { banyak } \\
\text { tetesan pasta }\end{array}$ & $\begin{array}{l}\text { Pembersihan mesin } \\
\text { creaming secara berkala, } \\
\text { operator diberikan tugas } \\
\text { tambahan untuk melakukan } \\
\text { pembersihan. }\end{array}$ \\
\hline
\end{tabular}


Tabel 11. Alternatif Perbaikan pada Modus Kegagalan Faktor Machine

\begin{tabular}{|l|l|}
\hline \multicolumn{1}{|c|}{$\begin{array}{c}\text { Modus } \\
\text { Kegagalan } \\
\text { Potensial }\end{array}$} & \multicolumn{1}{c|}{ Pengendalian } \\
\hline $\begin{array}{l}\text { Mesin } \\
\text { berjalan } \\
\text { tidak } \\
\text { konsisten }\end{array}$ & $\begin{array}{l}\text { Membuat jadwal dan } \\
\text { instruksi perawatan mesin } \\
\text { oven. }\end{array}$ \\
\hline $\begin{array}{l}\text { Loyang yang } \\
\text { mengalami } \\
\text { pemuaian }\end{array}$ & $\begin{array}{l}\text { Menambah } \text { blower atau } \\
\text { kipas angin sebagai } \\
\text { pendingin yang diletakan di } \\
\text { depan mesin } \text { oven untuk } \\
\text { mengurangi suhu. }\end{array}$ \\
\hline $\begin{array}{l}\text { Mesin } \\
\text { creaming } \\
\text { yang bocor } \\
\text { samping }\end{array}$ & $\begin{array}{l}\text { Melakukan jadwal } \\
\text { perawatan dan pembetulan } \\
\text { untuk mesin } \text { creaming yang } \\
\text { mengalami kebocoran } \\
\text { samping. }\end{array}$ \\
\hline
\end{tabular}

\subsection{Tahap Control}

Tahap control yang dijelaskan pada penelitian ini merupakan bentuk saran untuk melanjutkan proyek yang telah dilakukan agar dapat membantu untuk pengendalian kualitas ke arah yang lebih baik. Setelah dilakukan perbaikan dan peningkatan proses pada tahap sebelumnya, tetap perlu diketahui perkembangan kualitas produk yang dihasilkan melalui nilai sigma terbaru yang dimiliki proses. Selanjutnya, dilakukan tahap control terhadap perbaikan-perbaikan yang telah dilakukan dengan menggunakan tools seperti check sheet, quality report, control chart, serta akan dilakukan pendokumentasian.

\section{Check Sheet}

Tahap pengontrolan ini sangat diharapkan melibatkan operator dalam melakukan pencatatan data cacat produk yang terjadi pada area masing-masing.

2. Quality Report

Quality report dibuat guna memantau kualitas dari produk yang dihasilkan dengan cara menghitung semua jenis defect yang muncul dan jumlah produksi pada tiap shiftnya.

3. P Chart

Perlunya dilakukan pengendalian kualitas secara statistik dengan menggunakan $p$ chart yang dapat dibuat dengan melakukan perhitungan proporsi cacat yang diperoleh dari check sheet.

4. Pendokumentasian

Dalam melakukan pengimplementasian, perlu dilakukan pendokumentasian guna menciptakan suatu standarisasi baru. Hal ini merupakan upaya untuk mencegah adanya kecenderungan suatu sistem baru akan kembali ke sistem atau pola kerja yang lama.

\section{KESIMPULAN DAN SARAN}

Berdasarkan hasil pembahasan, dapat disimpulkan beberapa hal sebagai berikut:

1. Dari dua proses yang dilewati untuk menghasilkan produk wafer abon, yaitu proses oven and cooling sheet (35\%) dan proses creaming and pressing (65\%). Pemecahan masalah akan difokuskan kepada proses creaming and pressing yang memberikan kontribusi cacat lebih besar.

2. Dari 20 data yang diambil selama pengamatan terdapat sebanyak 11 data berada di luar batas pengendalian. Data tersebut berada di atas batas pengendalian atas (UCL) menandakan semakin besarnya persentase defect yang terjadi dan juga variasi yang terjadi masih cukup tinggi. Setelah dibuat peta kontrol revisi, hanya tertinggal 9 data yang berada dalam batas pengendalian dengan nilai $\overline{\mathrm{P}}_{\text {revisi }}=0,08489$; $\mathrm{UCL}=0,10922$; $\mathrm{LCL}=0,06056$. dan nilai kapabilitas proses sebesar $91,51 \%$.

3. Nilai sigma dalam proyek Six Sigma didapatkan hasil tingkat kualitas produk wafer abon berada pada level $3,65 \sigma$ dengan jumlah defect yang ada mencapai 219120 DPMO dari 8 jenis CTQ.

4. Jenis defect yang dominan ada pada jenis defect; pasta tidak rata $(53,7 \%)$, hancur pinggir $(16,3 \%)$, retak $(16,1 \%)$. Ketiga jenis defect tersebut akan dijadikan prioritas dalam penanganan masalah.

5. Penyebab defect yang terjadi sebagian besar disebabkan oleh faktor method dan machine. Sebagian besar penyebab terjadinya defect adalah karena kurang jelasnya metode dalam melaksanakan proses produksi itu sendiri. 
6. Usulan perbaikan utama yang dapat diberikan adalah:
a. Pembuatan standar ketinggian mesin creaming
b. Pemberian minyak secara berkala
c. Pembersihan mesin creaming secara berkala
d. Membuat jadwal dan instruksi perawatan mesin oven.
e. Menambah blower atau kipas angin sebagai pendingin.
f. Melakukan jadwal perawatan dan pembetulan untuk mesin creaming yang mengalami kebocoran samping.

\section{DAFTAR PUSTAKA}

1. Breyfogle, F.W. (1999). Business Deployment: A Leaders' Guide for Going Beyond Lean Six Sigma.

2. Evans, J.R., Lindsay, W.M. (2007). An Introduction to Six Sigma \& Process Improvement Pengantar Six Sigma. Salemba Empat, Jakarta.

3. Gaspersz, V. (2002). Pedoman Implementasi Program SIX SIGMA Terintegrasi dengan ISO 9001:2000, $M B N Q A$ dan HACCP. PT. Gramedia Pustaka Utama, Jakarta.

4. Mikel, J.H., Schroeder, R.R. (2006). The Breakthrough Management Strategy Revolutionizing the World's Top Corporation. Random House Digital, Inc.

5. Pande, P.S., Neuman, R.P., Cavanagh, R.R. (2007). The Six Sigma Way. Andi, Yogyakarta. 